\title{
The long-term results of cemented Oxford unicompartmental knee arthroplasty: A single-center experience
}

\author{
Çimentolu Oxford unikompartmental diz artroplastisinin uzun dönem sonuçları: \\ Tek merkez deneyimi
}

\author{
Gökhan Bülent Sever, MD1 (D), Cenk Cankuş, MD² (D) \\ 'Department of Orthopedics and Traumatology, Sani Konukoğlu Private Hospital, Gaziantep, Turkey \\ ${ }^{2}$ Department of Orthopedics and Traumatology, Sanko University School of Medicine, Gaziantep, Turkey
}

\begin{abstract}
Objectives: This study aims to investigate the long-term clinical outcomes, complications and survival rates of cemented Oxford medial unicompartmental knee arthroplasty (UKA) and to compare the findings with the reported outcomes of UKA and total knee arthroplasty (TKA) in the literature.
\end{abstract}

Patients and methods: In the study, 133 knees of 115 patients (16 males, 99 females; mean age $65.5 \pm 8.3$ years; range, 50 to 88 years) who underwent Oxford medial UKA between May 2007 and August 2013 were followed-up for an average of 126 months. Prosthetic complications and revisions were evaluated. While Kaplan-Meier method was used to evaluate implant survival, Knee Society, Functional Knee Society and visual analog scale scores were used for determining final functional outcomes.

Results: Totally 29 prosthetic complications $(21.6 \%$ of total patients) were observed and the most common one was insert dislocation observed in 17 knees (12.6\%). Revision surgeries were performed for all of these patients. Among the 17 patients who underwent insert replacement surgeries, the inserts were stable in eight during the follow-up while insert dislocation reoccurred in nine. Revision surgeries were performed in a total of 21 patients (15.6\%). There were statistically significant improvements in final follow-up functional knee scores of patients without complications compared to preoperative scores.

Conclusion: According to our findings, while reoperation and early aseptic revision rates of Oxford medial UKA are high compared to the TKA results reported in the literature, functional results are satisfactory for patients with no revision.

Keywords: Long-term outcomes, revision rates, unicompartmental knee arthroplasty.

\section{öz}

Amaç: $\mathrm{Bu}$ çalışmada çimentolu Oxford medial unikompartmental diz artroplastisi (UDA)'nin uzun dönem klinik sonuçları, komplikasyonları ve sağkalım oranları araştırıldı ve bulgular UDA ve total diz artroplastisi (TDA)'nin literatürde bildirilen sonuçları ile karşılaştırıldı.

Hastalar ve yöntemler: Çalışmada Mayıs 2007-Ağustos 2013 tarihleri arasında Oxford medial UDA uygulanan 115 hastanın (16 erkek, 99 kadın; ort. yaş $65.5 \pm 8.3$ yıl; dağılım, 50-88 yıl) 133 dizi ortalama 126 ay takip edildi. Protez komplikasyonları ve revizyonları değerlendirildi. İmplant sağkalımını değerlendirmek için Kaplan-Meier yöntemi kullanılırken son fonksiyonel sonuçları belirlemek için Diz Derneği, Fonksiyonel Diz Derneği ve görsel analog ölçeği skorları kullanıldı.

Bulgular: Toplam 29 protez komplikasyonu (toplam hastaların \%21.6'sı) gözlendi ve en yaygın olanı 17 dizde (\%12.6) görülen insert çıkı̆̆ıydı. Tüm bu hastalara revizyon cerrahisi yapıld. Insert replasman cerrahisi uygulanan 17 hastadan sekizinde takipte insert stabil iken, dokuzunda tekrar insert çıkığı gelişti. Toplamda 21 hastaya (\%15.6) revizyon cerrahisi yapıldı. Komplikasyon olmayan hastaların son takip fonksiyonel diz skorlarında ameliyat öncesi skorlara göre istatistiksel olarak anlamlı iyileşme vard1.

Sonuç: Bulgularımıza göre, Oxford medial UDA'nın literatürde bildirilen TDA sonuçlarına göre yeniden ameliyat ve erken aseptik revizyon oranları yüksek olmakla beraber fonksiyonel sonuçlar revizyonu olmayan hastalar için tatmin edici idi.

Anahtar sözcükler: Uzun dönem sonuçlar, revizyon oranları, unikompartmental diz artroplastisi.

Received: April 25, 2019 Accepted: July 16, 2019 Published online: October 24, 2019

Correspondence: Gökhan Bülent Sever, MD. Özel Sani Konukoğlu Hastanesi Ortopedi ve Travmatoloji Bölümü, 27090 Şehitkamil, Gaziantep, Turkey. Tel: +90 531 - 9927927 e-mail: gokhanbsever@yahoo.com 
Treatment options for medial compartment osteoarthritis of the knee include unicompartmental knee arthroplasty (UKA), total knee arthroplasty (TKA) and high tibial osteotomy. Although UKA was firstly described in the early 1950s, UKA application has been receiving growing interest particularly over the past 25 years ${ }^{[1]}$ since minimally invasive surgeries have been currently more favorable. ${ }^{[2,3]}$ Due to the difficulty of the learning curve at the beginning and limited availability of the literature on clinical outcomes, surgeons have generally avoided this surgery in the past.

Oxford UKA, described by Goodfellow and O'Connor, was firstly used in 1982. ${ }^{[4]}$ The Oxford medial UKA prosthesis was introduced with the following arguments: it can be used with minimally invasive approach, the extensor mechanism is preserved without luxation of the patella during the surgery and it can reduce debris formation with the use of mobile insert. When further studies also supported these arguments with short- and long-term clinical outcomes, its use has become widespread. ${ }^{[4,5]}$ However, higher revision rates compared to TKA reported in the registry data of different countries led orthopedic surgeons to approach this surgery cautiously. ${ }^{[6-9]}$

Several studies have also been performed in Turkey, reporting successful short- and mid-term clinical outcomes of Oxford UKA. ${ }^{[10,12]}$ However, the presence of controversial data reported in the literature encouraged us to investigate the longterm clinical outcomes of Oxford UKA with a large number of cases which could potentially contribute to the controversial notion of UKA in the literature. Accordingly, in this study, we aimed to investigate the long-term clinical outcomes, complications and survival rates of cemented Oxford medial UKA and to compare the findings with the reported outcomes of UKA and TKA in the literature.

\section{PATIENTS AND METHODS}

This retrospective single-center study was conducted at Sani Konukoğlu Private Hospital Department of Orthopaedics and Traumatology and included patients who underwent cemented mobile bearing Oxford UKA for knee medial compartment osteoarthritis between May 2007 and August 2013. Patients who underwent surgical treatment for secondary osteoarthritis (inflammatory arthritis, history of complex knee surgery, history of trauma), lateral UKA, medial UKA with fix insert, and TKA surgeries were excluded. Indications of medial UKA were: (i) presence of isolated medial compartment osteoarthritis, (ii) clinical and intraoperative evaluation of anterior cruciate ligament (ACL) intact, (iii) less than 10 degrees of flexion contracture, (iv) more than 90 degrees of flexion range of motion, $(v)$ less than 15 degrees of varus deformity improved by manual stress graphy and, (vi) less than 10 degrees of valgus deformity. Body mass index and patellofemoral arthrosis without pure anterior knee pain were not accepted as contraindication criteria. A total of 187 knees of 156 patients who met these criteria were included in the study. However, five of these patients died during the study and 36 patients could not be reached at the final follow-up visit. Therefore, radiological and clinical evaluations were conducted on 133 knees from 115 patients (16 males, 99 females; mean age $65.5 \pm 8.3$ years; range, 50 to 88 years). The study protocol was approved by the Sani Konukoğlu Private Hospital Ethics Committee. A written informed consent was obtained from each patient. The study was conducted in accordance with the principles of the Declaration of Helsinki.

Radiological evaluation of the patients with lateral, patellar tangential radiographs and anteroposterior knee radiographs in standing position was performed on both knees preoperatively and at final visit. No arthroscopy was performed during the surgery. In all cases, the lateral compartment and ACL were observed after the initial exposure. TKA was performed in one patient who had cartilage loss in all compartments during the same session. After the surgical operation, the patients were followed-up at first, third, sixth months and annually. The patients who did not regularly attend the annual follow-ups were still tried to be reached at the last control. The patients were evaluated clinically based on the Knee Society Score (KSS), Functional Knee Society Score (FKSS), visual analog scale (VAS) score and radiological data. The evaluation of the components and the radiolucent area, if any, was performed using the method described previously by Gulatin. ${ }^{[13]}$ All patients who underwent revision due to tibia loosening were indicated by X-ray and scintigraphy. Kaplan-Meier index was used for determining the implant surveillance.

\section{Statistical analysis}

Statistical analysis were carried out using SPSS version 15.0 software program (SPSS Inc., Chicago, IL, USA). The probabilities of uncomplicated survival and the uncomplicated mean time were obtained using the Kaplan-Meier method for all groups and age groups. As descriptive statistics, mean \pm standard deviation or median (minimum-maximum) values were reported for continuous data while percentage 
TABLE I

Clinical outcomes in patients without complications

\begin{tabular}{|c|c|c|c|c|c|c|c|}
\hline & \multicolumn{2}{|c|}{ KSS } & \multicolumn{2}{|c|}{ FKSS } & \multicolumn{2}{|c|}{ VAS } & \multirow[b]{2}{*}{$p$} \\
\hline & Median & Min-Max & Median & Min-Max & Median & Min-Max & \\
\hline Preoperative & 58.2 & $46-63$ & 56.8 & $46-61$ & 7 & $7-9$ & 0.001 \\
\hline Postoperative & 81.2 & $62-100$ & 77.9 & $54-100$ & 2 & $0-8$ & 0.001 \\
\hline
\end{tabular}

FKSS: Functional Knee Society Score; KSS: Knee Society Score; VAS: Visual analog scale.

and number values were reported for categorical data. The paired samples t-test was used for the preand postoperative values with normal distribution whereas the Wilcoxon signed-rank test was used if the values were not normally distributed. $\mathrm{P}$ value $<0.05$ was considered as statistically significant level for all analyses.

\section{RESULTS}

When all the patients who had no revision were evaluated together, a statistically significant improvement was observed in the clinical results. Knee Society Score was found to be 58.2 (range, 46-63) preoperatively while it was 81.7 (range, 62-100) at the final follow-up $(\mathrm{p}<0.05)$. Similarly, FKSS was found to be 56.8 (range, 46-61) preoperatively and it was 77.9 (range, 54-100) at the final follow-up $(\mathrm{p}<0.05)$. There was also a significant improvement in VAS values $(p<0.05)$. While the preoperative VAS value was 7 , it decreased to 2 at the final follow-up (Table I). In the final follow-up, KSS values were excellent in 77 knees, good in 25 knees, moderate in five knees, and poor in five knees. Also, FKSS values were excellent in 71 knees, good in 28 knees, moderate in five knees, and poor in eight knees.

Postoperative complications developed in 29 patients $(21.6 \%)$ and the most common complication was insert dislocation in 17 patients $(12.6 \%)$ (Figure 1a, b). For the patients with insert dislocation, the insert was changed with a thicker and/or anatomical insert initially. The insert dislocation reoccurred in nine patients (52.9\%). Revision with primary knee arthroplasty was performed in these patients. Eight patients (47.1\%) who did not develop any complication following
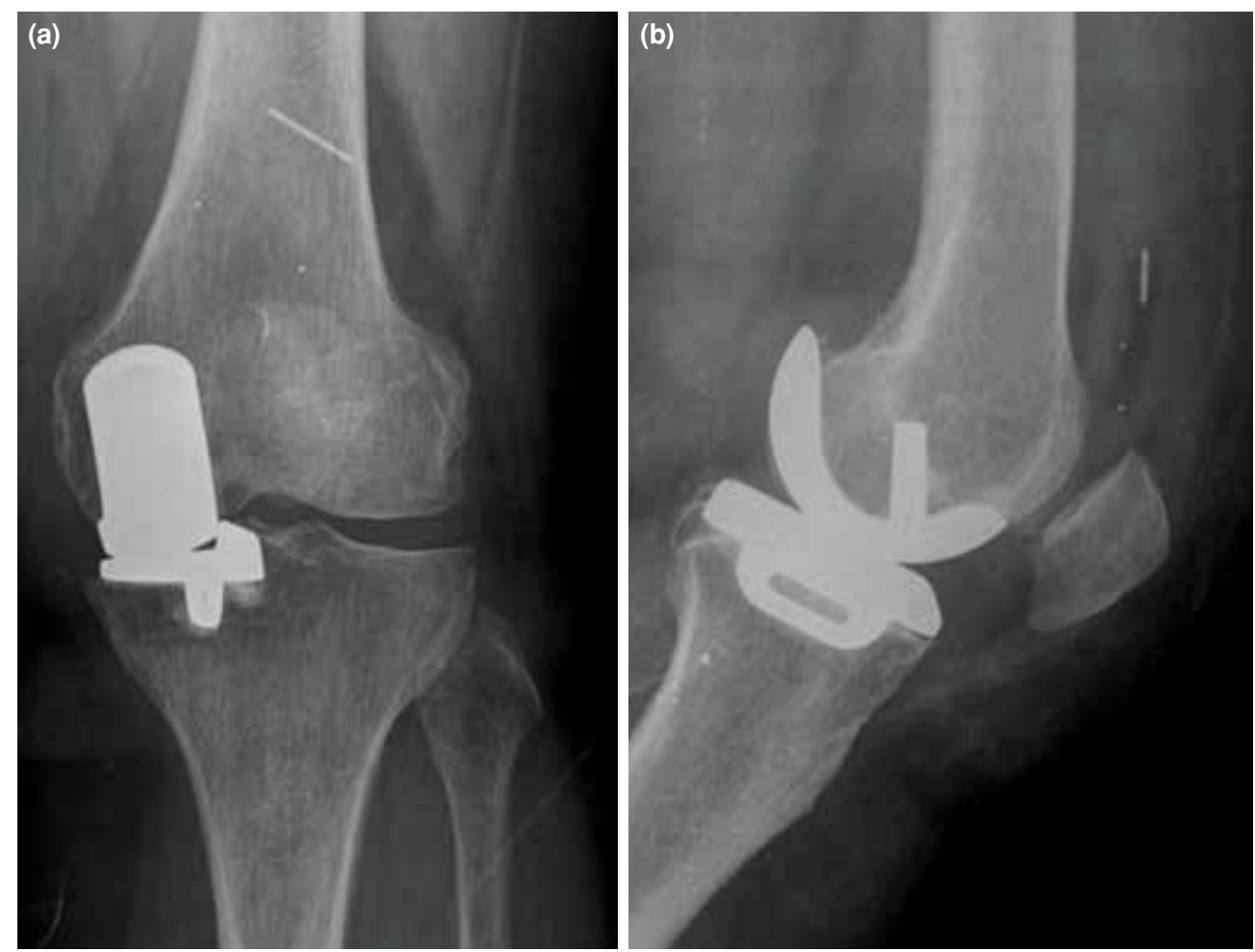

Figure 1. (a) Anteroposterior and (b) lateral graphies of insert dislocation. 

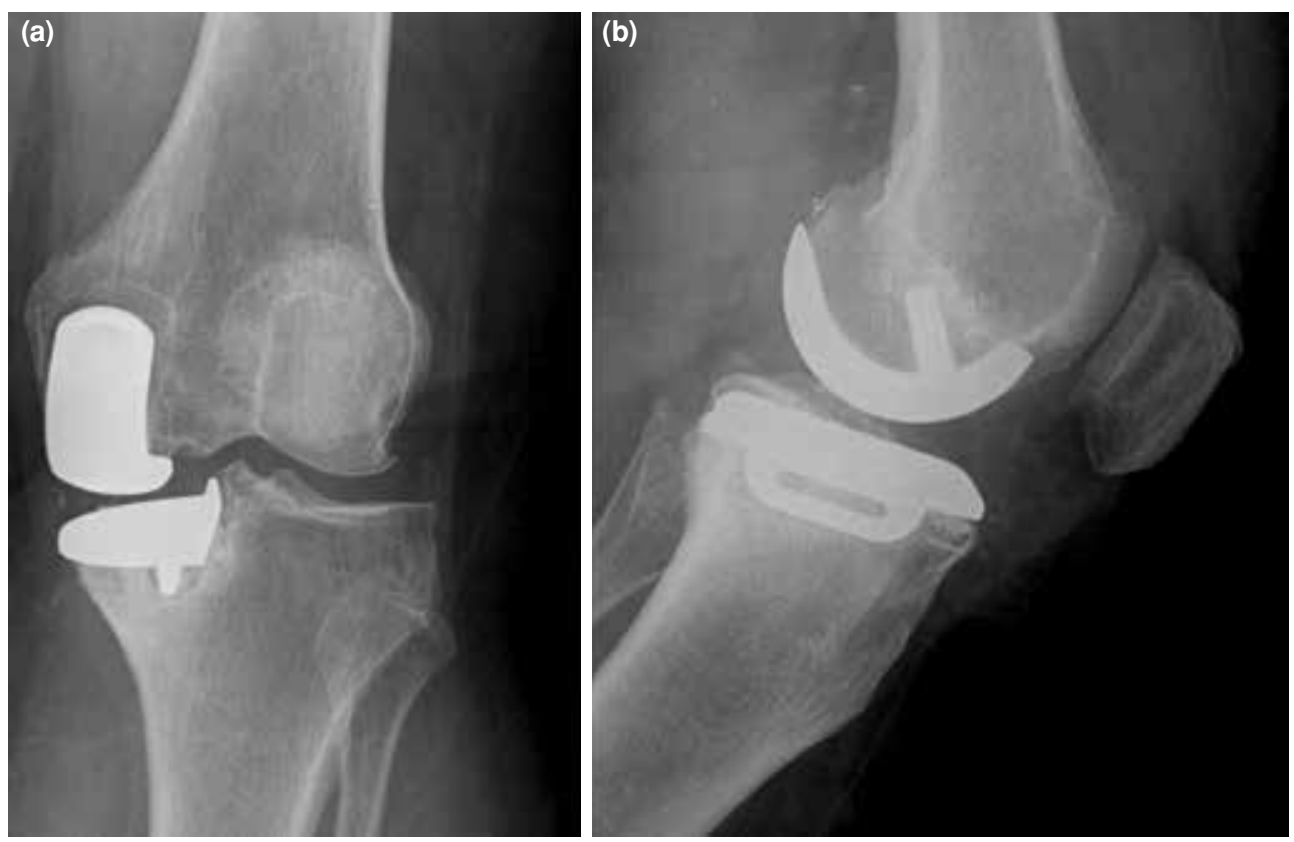

Figure 2. (a) Anteroposterior and (b) lateral graphies of tibial loosening.

the insert change were not included in the revision group. In these eight patients, anatomic insert was used for the insert change. Totally, 21 patients $(15.6 \%)$ underwent revision knee surgeries. Among them, revision surgeries were performed due to insert redislocation in nine patients, tibial loosening in seven patients (Figure 2a, b), lateral compartment arthrosis in two patients (Figure 3), patellofemoral arthrosis in one patient, medial joint pain in one patient and medial collateral ligament failure in one patient (Table II). Revision knee arthroplasty with primary total knee replacement (TKR) was performed in 19 patients and revision knee arthroplasty in two patients. Tibial extension stem was used in three of these 19 TKR patients (Figure $4 a, b)$. No infection was observed in any of the patients. The mean time to the revision was 72 months (range, 27-88 months). Unicompartmental knee arthroplasty survival rate by Kaplan-Meier index was $85.5 \%$ in 126 months (Figure 5).

Radiological examination revealed the existence of radiolucent area in $12(10.7 \%)$ stable knees. Based on the classification of Gulati et al. ${ }^{[13]}$ as criteria, the radiolucent areas were found to exist in localization six in the majority of patients $(n=9)$. The preoperative tibiofemoral angle was about 3 degrees of varus (ranges from 10 degrees varus to 5 degrees valgus) while the tibiofemoral angle was 3 degrees of valgus at the final follow-up (ranges from 5 degrees varus to 10 degrees valgus).

\section{DISCUSSION}

Findings of this study indicate that the rate of complications of mobile phase Oxford insertion UKA surgery was high and long-term survival was low. The rate of early revision related to aseptic causes was

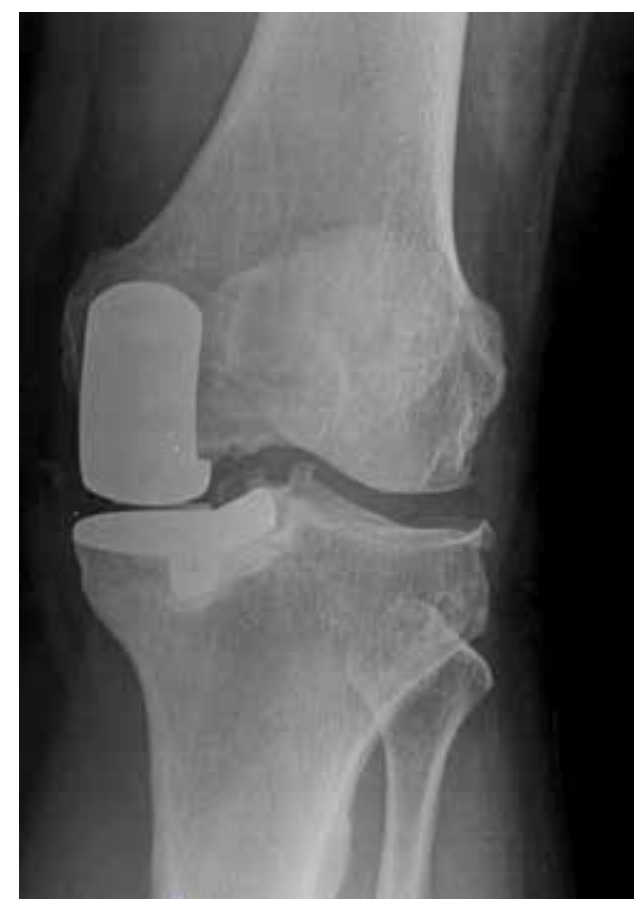

Figure 3. Anteroposterior graphy of knee lateral compartment arthrosis. 
TABLE II

Indications for revision

\begin{tabular}{lcc}
\hline Complications & No of cases & Treatment \\
\hline Mobile bearing dislocation & 9 & 9 Primary total knee replacement \\
Loose tibial component & 7 & 6 Primary total knee replacement \\
& & 1 revision total knee replacement \\
Lateral compartment arthrosis & 2 & Primary total knee replacement \\
Patellofemoral arthrosis & 1 & Primary total knee replacement \\
Persistent medial knee pain & 1 & Primary total knee replacement \\
Medial collateral ligament deficiency & 1 & Revision with hinged total knee replacement \\
\hline
\end{tabular}

also higher compared to the rate of TKA reported in the literature. ${ }^{[7-9]}$

While Oxford UKA is one of the most widely used UKA implants worldwide, contradictory data regarding to the outcomes of use of this implant have been reported. In 1998, the 10-year survival rate was first reported by the designer surgeons as $97.3 \% .{ }^{[14]}$ In addition, implant survival rates of $97 \%$ in seven years ${ }^{[14]}$ and $91 \%$ in 20 years $^{[15]}$ were previously reported. There are also contradictory results: in a study conducted in Sweden, a revision rate of $7 \%$ was reported at the end of six years. ${ }^{[6]}$ Authors of the abovementioned study suggested the use of this implant if the results of long-term and comparative studies were to be successful. ${ }^{[6]}$ Unicompartmental knee arthroplasty and TKA survival rates were compared in another study based on England and Wales registry data in 2014, which included 25,334 UKA and 75,996 TKA cases. $^{[7]}$ As a result of the study, TKA survival was found to be $94.6 \%$ while UKA survival was $87 \%$ on an average of eight-year follow-up. They further reported that the revision rates were higher in UKA cases and the most common reason of revision was aseptic loosening. ${ }^{[7]}$ In a 2008 study based on Finnish registry
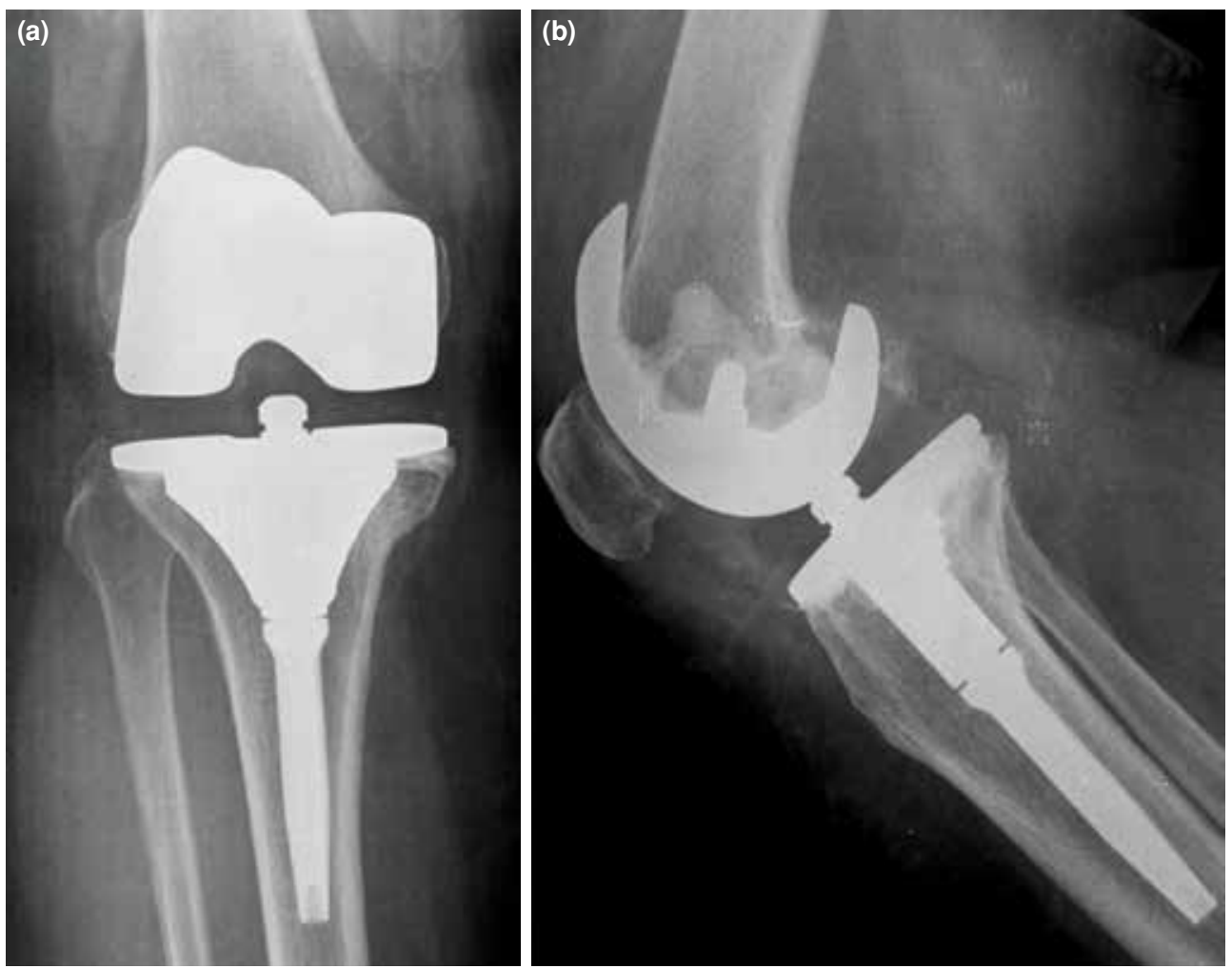

Figure 4. (a) Anteroposterior and (b) lateral graphies of revision of unicompartmental knee arthroplasty with primary total knee replacement. 


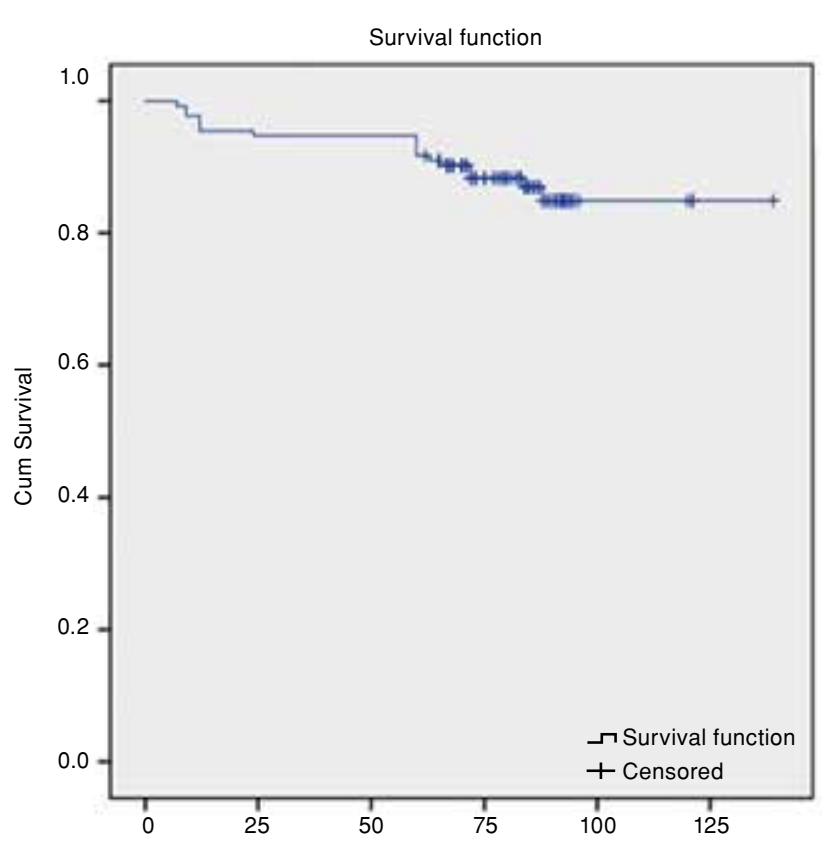

Figure 5. Kaplan-Meier survival curve of primary unicompartmental knee arthroplasty.

data, the UKA survival rate was $73 \%$ at mean 10 -year follow-up and $60 \%$ at 15 -year follow-up. In this study, TKA survival was reported as $90 \%$ in 10 years and $80 \%$ in 15 years. The authors concluded that the survival rate of UKA is low and the rate of revision is high, and that this surgery is not cost effective in contrast to the common belief that early revision is necessary due to the high rate of revision. ${ }^{[8]}$ In another multicenter study conducted in USA in 2019, UKA was reported to have higher revision rates compared to TKA at seven-year follow-up and have worse survival rate $(97 \%$ vs. $80 \%) \cdot{ }^{[9]}$ Other studies have also reported similar high revision rates over time. ${ }^{[16,17]}$

When compared with the long-term follow-up results of TKA $\left(90 \%{ }^{[7]}\right.$ and $\left.97 \% \%^{[8]}\right)$ in the registry data, the survival rate of UKA in our study was lower and the early revision rate due to aseptic reasons was higher. The complication rate in our study was found to be $21.6 \%$, the revision rate due to aseptic causes was $15.6 \%$ and the implant survival rate was $85.5 \%$ in 126 months.

Based on the studies comparing the clinical results of UKA with TKA, the clinical outcomes of both surgeries have been reported to be similar generally. ${ }^{[18,19]}$ Lyons et al ${ }^{[18]}$ compared the pre- and postoperative clinical outcomes of 5,606 TKA and 279 UKA surgeries with the Knee Society Clinical Rating System, the short form-12, and the Western Ontario and McMaster Universities Osteoarthritis Index scores, and showed better postoperative clinical scores in UKA compared to those of TKA. In the same study, they also reported that the change in pre- and postoperative scores was similar in both surgeries. ${ }^{[18]}$ The results of the abovementioned study also reported that the clinical scores of patients undergoing TKA in preoperative measurements were lower than those of the patients undergoing UKA. The improvement in clinical scores was at the same level in the postoperative period although the overall scores in TKA were lower than those in UKA, emphasizing that both surgeries had similar effect on improving clinical scores. ${ }^{[18]}$ In our study, KSS, FKSS and VAS scores were used to evaluate the clinical scores. In the evaluation of uncomplicated patients, the mean KSS/FKSS/VAS scores were 58.2 (46-63)/56.8 (46-61)/7 preoperatively and $81.7(62-100) / 77.9(54-100) / 2$ at the last follow-up. Statistically significant differences consistent with the literature were found between pre- and postoperative control times in KSS, FKSS and VAS scores $(\mathrm{p}<0.05)$.

It is commonly known that there is a learning curve for Oxford UKA. ${ }^{[20]}$ Meanwhile, the surgeon's experience and education are also important for performing Oxford UKA. In order to learn a new surgery, the surgeon must have surgical experience along with a high number of performed surgeries. ${ }^{[2]}$ In one study, it was reported that the surgeon must perform at least 14 Oxford UKA surgeries per year for a successful Oxford implantation. ${ }^{[22]}$ Another important criterion is that the rate of TKA/UKA in the clinic should be 3 . During the study period, 878 TKAs and 187 UKAs were performed in our clinic, resulting in a rate of approximately $4 / 1$ in our study.

Several studies on Oxford UKA have also been conducted in Turkey, reporting successful short- and mid-term clinical results. ${ }^{[10-12]}$ For example, Aslan et al., ${ }^{[10]}$ conducted a 28-month follow-up study on cemented Oxford UKA in 27 patients in 2007 and reported that only two (7.4\%) patients required revision surgery due to tibial collapse. Furthermore, in 2010, Parmaksızoğlu et al. ${ }^{[11]}$ reported the outcomes of 38 cases of cemented Oxford UKA for 24-month follow-up. They reported excellent outcomes with no patients having any complications. ${ }^{[1]}$ In another study, Cepni et al., ${ }^{[12]}$ reported the outcomes of 67 patients with obesity (body mass index >30) in 2014 for a mean of 67.5-month follow-up. They found no complications during this time period except three insert dislocations. ${ }^{[12]}$ The reported results of these studies are consistent with the early- and mid-term results reported by the Oxford designer surgeons. On the other hand, our findings are consistent with the studies using the registry data of England, Sweden, 
and Finland, suggesting that long-term follow-up studies with larger sample sizes are more reliable.

Although several studies have reported successful UKA results in Turkey, some researchers in Turkey have been approaching this surgery cautiously. For example, in a review published by Atik, ${ }^{[23]}$ it was clearly stated that surgeons were willing to perform UKA surgery that is a minimally invasive procedure offering shorter hospital and rehabilitation periods; however, they believed that it would not be appropriate to use a new design as a marketing tool until its effectiveness and safety are scientifically supported. ${ }^{[23]}$ The overall results of the current study also support the notion in the abovementioned review.

The limitations of our study were that it was a single-center study and all the surgeries were performed only by two surgeons. Therefore, future multicenter and comparative studies are required to further validate our findings.

In conclusion, in our study, the complication and aseptic revision rates of medial compartment osteoarthritis treatment with Oxford cemented UKA were higher than those of TKA rates reported in the literature. In line with this result, surgeons should be careful in selecting UKA for the treatment of medial compartment osteoarthritis of the knee. Therefore, based on our findings, we do not recommend the use of Oxford UKA surgery commonly in the treatment of medial compartment osteoarthritis.

\section{Declaration of conflicting interests}

The authors declared no conflicts of interest with respect to the authorship and/or publication of this article.

\section{Funding}

The authors received no financial support for the research and/or authorship of this article.

\section{REFERENCES}

1. Ritter MA, Faris PM, Thong AE, Davis KE, Meding JB, Berend ME. Intra-operative findings in varus osteoarthritis of the knee. An analysis of pre-operative alignment in potential candidates for unicompartmental arthroplasty. J Bone Joint Surg [Br] 2004;86:43-7.

2. Repicci JA1, Eberle RW. Minimally invasive surgical technique for unicondylar knee arthroplasty J South Orthop Assoc 1999;8:20-7

3. Murray DW, Goodfellow JW, O'Connor JJ. The Oxford medial unicompartmental arthroplasty: a ten-year survival study. J Bone Joint Surg [Br] 1998;80:983-9.

4. Müller PE, Pellengahr C, Witt M, Kircher J, Refior HJ, Jansson V. Influence of minimally invasive surgery on implant positioning and the functional outcome for medial unicompartmental knee arthroplasty. J Arthroplasty 2004;19:296-301.
5. Saxler G, Temmen D, Bontemps G. Medium-term results of the AMC-unicompartmental knee arthroplasty. Knee 2004;11:349-55.

6. Lewold S, Goodman S, Knutson K, Robertsson O, Lidgren L. Oxford meniscal bearing knee versus the Marmor knee in unicompartmental arthroplasty for arthrosis. A Swedish multicenter survival study. J Arthroplasty 1995;10:722-31.

7. Liddle AD, Judge A, Pandit H, Murray DW. Adverse outcomes after total and unicompartmental knee replacement in 101,330 matched patients: a study of data from the National Joint Registry for England and Wales. Lancet 2014;384:1437-45.

8. Koskinen E, Eskelinen A, Paavolainen P, Pulkkinen P, Remes V. Comparison of survival and cost-effectiveness between unicondylar arthroplasty and total knee arthroplasty in patients with primary osteoarthritis: a follow-up study of 50,493 knee replacements from the Finnish Arthroplasty Register. Acta Orthop 2008;79:499-507.

9. Hansen EN, Ong KL, Lau E, Kurtz SM, Lonner JH. Unicondylar knee arthroplasty has fewer complications but higher revision rates than total knee arthroplasty in a study of large united states databases. J Arthroplasty 2019;34:1617-25.

10. Aslan H, Ersan O, Baz AB, Duman E, Aydin E, Ateş Y. Midterm results of Oxford phase 3 unicondylar knee arthroplasty for medial osteoarthritis. Acta Orthop Traumatol Turc 2007;41:367-72.

11. Parmaksizoğlu AS, Kabukçuoğlu Y, Ozkaya U, Bilgili F, Aslan A. Short-term results of the Oxford phase 3 unicompartmental knee arthroplasty for medial arthritis. Acta Orthop Traumatol Turc 2010;44:135-42.

12. Cepni SK, Arslan A, Polat H, Yalçin A, Parmaksizoğlu AS. Mid-term results of Oxford Phase 3 unicompartmental knee arthroplasty in obese patients. Acta Orthop Traumatol Turc 2014;48:122-6.

13. Gulati A, Chau R, Pandit HG, Gray H, Price AJ, Dodd CA, et al. The incidence of physiological radiolucency following Oxford unicompartmental knee replacement and its relationship to outcome. J Bone Joint Surg [Br] 2009;91:896-902.

14. Pandit H, Jenkins C, Barker K, Dodd CA, Murray DW. The Oxford medial unicompartmental knee replacement using a minimally-invasive approach. J Bone Joint Surg [Br] 2006;88:54-60.

15. Price AJ, Svard U. A second decade lifetable survival analysis of the Oxford unicompartmental knee arthroplasty. Clin Orthop Relat Res 2011;469:174-9.

16. Chou DT, Swamy GN, Lewis JR, Badhe NP. Revision of failed unicompartmental knee replacement to total knee replacement. Knee 2012;19:356-9.

17. Schroer WC, Barnes CL, Diesfeld P, LeMarr A, Ingrassia R, Morton DJ, et al. The Oxford unicompartmental knee fails at a high rate in a high-volume knee practice. Clin Orthop Relat Res 2013;471:3533-9.

18. Lyons MC, MacDonald SJ, Somerville LE, Naudie DD, McCalden RW. Unicompartmental versus total knee arthroplasty database analysis: is there a winner? Clin Orthop Relat Res 2012;470:84-90.

19. Newman J, Pydisetty RV, Ackroyd C. Unicompartmental or total knee replacement: the 15-year results of a prospective randomised controlled trial. J Bone Joint Surg [Br] 2009;91:52-7. 
20. Hamilton WG, Ammeen D, Engh CA Jr, Engh GA. Learning curve with minimally invasive unicompartmental knee arthroplasty. J Arthroplasty 2010;25:735-40.

21. Barrett WP, Scott RD. Revision of failed unicondylar unicompartmental knee arthroplasty. J Bone Joint Surg [Am] 1987;69:1328-35.
22. Baker P, Jameson S, Critchley R, Reed M, Gregg P, Deehan D. Center and surgeon volume influence the revision rate following unicondylar knee replacement: an analysis of 23,400 medial cemented unicondylar knee replacements. J Bone Joint Surg [Am] 2013;95:702-9.

23. Atik OS. Unicompartmental or total knee arthroplasty? Eklem Hastalik Cerrahisi 2011;22:118-9. 